\title{
From the Stereotypification of the Non-European Other to the Prototypification of the European Self: A Case Study of Turkey's Membership to the European Union from the French Perspective
}

\author{
Ariane Bogain and Florence Potot, Northumbria University
}

Since the Rome Treaty of 1957, the conception of Europe in the collective psyche has been gradually confused with membership to the evolving European Union (EU). Although expansion is intrinsic to the nature of the EU, the context of increasing globalisation of the past decade has emphasized the role of supranational organisations and thus accelerated its expansion process. Whilst until the last enlargement in 2004 citizens throughout the member states supported the membership of new countries, the press and opinion polls carried out across those member countries show a clear opposition to Turkey's entry into the EU. Interestingly, the debate surrounding Turkey's application to join the EU, though not new, has raised salient issues such as the notion of European identity, European culture, and European values, thus stressing the confusion between Europe and the EU and implying that membership itself is the concrete representation of a corpus of commonality shared by members. Whether in the French press or in opinion polls, issues about Europe in general and the EU in particular arise in terms of identity, suggesting that the sense of belonging to a nation that exists at country level can be extended to the EU level. This confusion is fuelled by the press and political discourse; in both the terms Europe and European are used liberally to refer to the European Union and its citizens, thus implying that non-member countries might be non-European and therefore perceived as the other different from the self. 
Turkey's potential membership to the EU epitomizes this dichotomy because beyond the question of the EU's limits it leads to questioning the EU rationale. Whilst opinion polls show concerns about Turkey joining the EU in various countries, the debate is particularly earnest in France where it has become a matter of national import through the "No" vote on the European Constitution in May 2005. Consequently, the purpose of this study is to analyse French arguments, both in the press and in opinion polls, against Turkey's membership in order to determine whether or not a prototypification of Europe, as the self, can be drawn from the French stereotypification of Turkey, as the nonEuropean other. The study thus focuses explicitly on the relationship between stereotype and prototype. In other words, this study explores what the French rejection of Turkey reveals about the concept of Europeanness in the French collective psyche. In the first part of the essay, we identify the salient traits commonly associated in France with Turkey on the one hand, and Europe and Europeans on the other. The essay's second part analyses the notion of Europeanness drawn from these representations and evaluates to what extent that concept of Europeanness is the antithesis of the stereotypical representation of Turkey as the non-European other, since as pointed out by Nachbar and Lause 'common stereotypes directly reflect our beliefs' (1992, 244).

\section{Methodology}

For the purpose of this study, a stereotype is defined as a belief, opinion, or representation held about a group and its members (Amossy and Herschberg-Pierrot 2004, 28). In other words, the stereotype of Turkey refers here to a collective image based on the traits typically associated with Turkey in France. Nachbar and Lause (1992, 236) refer to stereotypes as 'mental cookie cutters,' standardised conceptions that simplify a complex reality by associating a set of characteristics, often related to age, sex, race, religion, vocation or nationality, to the members of a group. Although a stereotype is at once a non-critical judgement and a form of second-hand knowledge, the stereotypification process is considered in social sciences to be a constructive part of the cognitive process. That is simplification and generalisation, even if sometimes excessive, are necessary to compare new situations or groups to familiar pre-existing models and thus understand the world, and plan and adapt our behaviour accordingly. A stereotype is: 'un concept bien défini qui permet d'analyser le rapport de l'individu à l'autre et à soi, ou les relations entre les groupes et leurs membres individuels' [a well defined concept that facilitates/enables the analysis of the relationship of an individual 
to the other and to him/herself or the relationships between groups and their individual members] (Amossy and Herschberg-Pierrot 2004, 28). ${ }^{1}$ As standardised conceptions, stereotypes generate by their very existence a commonality shared by members of a designated group about members of another group. According to Nachbar and Lause 'Popular stereotypes are images which are shared by those who hold a common mindset-they are the way a culture, or significant sub-group within that culture, defines and labels a specific group of people' $(1992,236)$. Consequently a stereotypical representation held by a specific group is derived from their beliefs and values. Therefore it can be argued that 'a stereotype is a valuable tool in the analysis of popular culture because once the stereotype has been identified and defined, it automatically provides us with an important and revealing expression of otherwise hidden beliefs and values' (Nachbar and Lause 1992, 236).

The concept of prototype originally appeared in cognitive psychology to refer to 'les processus de catégorisation dans le cadre plus général de l'étude des structures des connaissances en mémoire humaine' [the categorisation processes involved in the wider study of structures of types of knowledge in human memory] (Dubois and RescheRigon 1993, 373). However, for the purpose of this study, we mainly concentrate on the semantics of prototypes that establish a relationship of equivalence between category and word. The notion of prototype used here refers to the concept or mental representations associated with a term; it is ' le meilleur exemplaire communément associé à une catégorie' [the best example commonly associated with a category] (Kleiber 1990, 49). This implies that a prototype is a sub-category that typically represents the category associated with it, because it includes its most salient characteristics, and that there might be more than one prototype associated with any given category. From this point of view, protypification is the result of a process of typification and graduation (Amossy and Herschberg Pierrot 2004, 93). In other terms, one prototype does not possess all the characteristics associated with the related specific category and all members of the category do not possess all the characteristics of the prototype. In this essay, the EU is a prototype of Europe, and therefore the French concept of European is a prototype of Europeanness. A prototype does not identify itself with the actual group but with the concept associated with the group (Kleiber 1990, 62).

\footnotetext{
${ }^{1}$ All translations in this essay are ours.
} 
This study uses the psycho-linguistic notion of prototypes that defines prototypes as being instrumental to the semantic categorisation of a group.

This study is based on information extracted from public opinion polls carried out in France and Eurobarometers surveys published by the European Commission, as well as from articles published between 2002 and Spring 2006 in three French national daily newspapers. 2002 was chosen as the starting point given that in November of that year, Mr Valéry Giscard D’estaing, former French President and President of the European Convention in charge of the drafting of the European Constitution, declared that 'la Turquie est un pays proche de l'Europe, un pays important, qui a une véritable élite, mais ce n'est pas un pays européen' [Turkey is a country close to Europe, an important country with a true elite, but it is not a European country] (De Bresson 2004) and that to open the door to Turkey would lead to the end of the EU. Furthermore, the start of negotiations with a view to granting Turkey full EU membership was agreed in 2002, at the Copenhagen Summit. The three daily newspapers were selected on the basis of the political preferences they display: Le Figaro on the right of the political exchequer; Libération on the left; and Le Monde in the centre. Those newspapers underpin this study because the choice of lexis and personalities invited to write in the daily press is a very important factor in the stereotypification process. Indeed, stereotypes are secondhand knowledge acquired through cultural mediators who, voluntarily or not, contribute to the creation and the circulation of their own stereotypical representations based on their own beliefs and values. The stereotype will carry even more credit if the 'truth' is transmitted in articles written by 'reliable' experts. In the case of Turkey, it has to be noted that all three newspapers have resorted to experts, such as Robert Badinter, a former president of the Constitutional Council and a former minister for Justice, and Valery Giscard D'estaing, to either justify or oppose Turkey's application to join the EU, thus giving more weight to the opposed arguments on the Turkey-EU question.

\section{Typology of arguments against Turkey's membership}

Opinions polls carried out at national or European levels since 2002 show that a clear majority of French people, irrespective of gender, age, professional status or education (although opposition strengthens with age or poorer education), oppose the possible enlargement of the EU to include Turkey. This rejection of Turkey's membership is evaluated at between $64 \%$ and $68 \%$ in the Eurobarometer polls, and between $56 \%$ and 
$75 \%$ in national polls for the 2002-2005 period (European Commission 2002, 2003b, 2004, and 2005; Ipsos 2002, 2004; Ifop 2005). This rejection is not simply widespread; it is also entrenched, as shown by the fact that despite legal assurances that a referendum would be held in France on this matter before Turkey is granted full membership, 22\% of French people rejected the European Constitution as an expression of opposition to Turkey (Louis Harris 2005). That entrenching of anti-Turkey viewpoints is also demonstrated by the fact that the application of countries such as Morocco and Tunisia, which many respondents would not class as European, would have more support (Morocco: 36\% in favour, Tunisia 35\%, Turkey 30\%) (TNS-Sofres 2005a, 2006). Moreover, unlike in other EU countries, French opposition to Turkey's EU membership does not reflect a clear stance from political parties. Although opponents to Turkey's membership are found more frequently in conservative parties, despite the support displayed by Mr Chirac, the French Socialist party is greatly divided on the issue, as are many parties on the left.

Thus, although the rejection of Turkey is deeply entrenched, the degree of opposition varies and many political parties, trade unions and political clubs are also divided on the issues, as reflected in newspaper headlines. In a dossier entitled 'Le débat français sur l'adhésion de la Turquie à l'UE' [The French debate surrounding Turkey's accession to the EU], which suggests that a consensus is far from being reached, Le Monde (2004) compiled articles that confirm the difficulty of categorising arguments for or against Turkey's membership according to political parties. Amongst its contents are titles such as 'Valéry Giscard d'Estaing dénonce 1' “ambiguité” française face à la Turquie' [Valéry Giscard d'Estaing denounces the ambiguity of the French towards Turkey]; or, 'Le processus d'adhésion de la Turquie à l'UE avive les tensions au PS et à droite' [Turkey's accession process to the EU fuels tension within the Socialist Party and the Right]. Not only is the lack of consensus underlined by these articles, but it is also given magnitude by quoting such a key figure for the future shape of the EU as Valéry Giscard d'Estaing, who led the Convention on the European Constitution. With the headlines 'A l'Assemblée nationale, les députés préfèrent un "partenariat privilégié" avec la Turquie à son adhésion à l'UE' [MPs favour a privileged partnership over full membership], Le Monde shows that the issue of Turkey's membership splits the highest institutional levels of the country, with a parliament mainly against full membership, whilst the head of State, namely Mr. Chirac, supported it. The Right is not the only 
political sector to be divided, for the Left, and the Socialist Party in particular, is too. Isabelle Mandraud (2005) indeed points out in that 'le PS, embarrassé, hésite à définir clairement sa propre vision des frontières de l'Europe' [The embarrassed Socialist Party is reluctant to give an explicit of its views on Europe boundaries].

What is at stake in this debate is not so much what Turkey is or is not, but rather the questions and uncertainties it raises about Europe, and most particularly the EU, considered in terms of the definition of the self as opposed to the other. This refers directly to the notion of identity in group terms. Like social identity, national or here 'supra-national' identity results from what Fishman calls

l'adhésion à une opinion entérinée, une image partagée, (qui) permet à l'individu de proclamer indirectement son allégeance au groupe dont il désire faire partie. Il exprime en quelque sorte son allégeance à une collectivité en assumant ses modèles stéréotypés. $(1956,40)$

[Supporting a well-known opinion, a shared image enables the individual to claim indirectly its allegiance to the group he/she wants to belong to. Somehow he/she expresses his/her allegiance to a group by endorsing its stereotypical models.]

This division is apparent in the terminology used to refer to Turkey's opponents in the press, which reflects the division of intellectuals, politicians and public opinion over Turkey's membership of the EU, thus revealing the set of beliefs or values they adhere to. Terms used range from 'Turcosceptics' in Le Monde to 'Turcophobics' in Libération. Whilst Libération mentions the humiliating way the EU is treating Turkey by reneging on the promises made over the past four decades and adding requirements to the Copenhagen criteria as prerequisites for Turkey's membership, Le Figaro stresses that Turkey's inadequacies make it incompatible with EU countries. Libération, however, also acknowledges that in the case of Turkey, the application to join the EU is 'une candidature à handicap' [An application riddled with difficulties], but unlike Le Figaro does not see any incompatibility between Turkey and the EU. For its part, Le Monde describes the 'defi turc' [Turkish challenge].

These reasons for rejecting Turkey's potential membership need to be assessed critically. In the literature on enlargement a number of models have been used to evaluate the reasons for accepting or rejecting the process, including Eichenberg and Dalton's rationality and identity model (1993) or Deutsch et al's transactionalist model (1957). In this paper, however, we have chosen Sjursen's model (2002). Informed by Habermas's 
classification (1993), ${ }^{2}$ the model's analytical distinctions between pragmatic, ethicalpolitical, and moral arguments enables us to evaluate the reasons for accepting or refusing the enlargement process. We use this model to draw the collective image based on the typical traits currently associated with Turkey and conversely with Europe. For each of the categories described below, the arguments against Turkey's membership are contrasted with French people's responses to opinion polls on the image European citizens hold of Europe, our aim being to identify the salient traits that could define a stereotype of Turkey and a French prototype of Europe and the Europeans.

Pragmatic arguments are means-ends calculation of utility, based on considerations of costs and benefits (new markets, more power, more prestige). Many such arguments have been proposed by opponent's of Turkey's EU entry: it is not economically and socially developed enough (for example, $77 \%$ mentioned that it was too far behind economically [European Commission 2005]), and these disparities will lead to mass immigration towards the richer countries $(64 \%$ in the same poll mentioned that Turkey's accession would increase immigration). Moreover, the EU would not be stable with a volatile region in its midst (thus in that poll 55\% felt that Turkey's entry would not improve the relationship with Islam, and 54\% that it would not improve security in the region). The same arguments are put forward in the press as epitomised by Robert Badinter (2005) in Le Monde when he questions what he calls the obstinant support for Turkey's membership and rejects every pro-membership argument put forward:
Ce n'est pas pour combattre le chômage. Le salaire moyen des travailleurs turcs est inférieur à celui pratiqué dans l'Europe des Quinze et leurs avantages sociaux sont très limités. Le risque d'accroitre les délocalisations au sein du marché unique est plutôt accru. Ce n'est pas pour favoriser l'agriculture française. La population agricole en Turquie représente environ le tiers de la population. La moyenne dans l'UE est de 5\%. La PAC devra donc nécessairement être transformée pour permettre aux agriculteurs turcs de subsister ou de se reconvertir dans d'autres activités. Ce n'est pas non plus pour améliorer ou équilibrer le budget européen. Le coût de l'intégration de la Turquie sera au moins égal à celui des dix nouveaux adhérents à l'Union européenne.
[It is not to fight unemployment - the average wage in Turkey is lower than that of the European Union prior to its latest enlargement and social benefits are extremely basic. The risk of relocation within the EU is even greater. It is not to support French farming - about a third of Turks are farmers. The average farming population in the EU is 55\%. Therefore the CAP will have to be reviewed to enable Turkish farmers to survive or opt for other activities. It is not to improve or

\footnotetext{
2 In his theory of communication action Habermas stated that the bedrock of liberal democracy is actors' rationality, i.e. their ability to justify their actions, understand the various forms of justifications put forward in a communication setting and determine which ones are acceptable or not. These reasons can be pragmatic (personal gain), they can be based on kinship and a sense of identity or they can be based on universal standards of justice.
} 
balance European finances - expanding the EU to Turkey would cost at least as much as it did for the 10 new members states.

These arguments suggest, on the one hand, that French people see Europe as an economically and socially advanced community, and, on the other hand, that they feel those high standards may be under threat. Thus the negative attitude towards Turkey clearly suggests a fear of economic difficulties and increased competition from a lowwaged country with its potential impact on unemployment rate, standards of living and social provisions. Clearly, according to this attitude, Turkey cannot be integrated into the EU because it does not share pragmatic characteristics with 'Europe,' and is therefore definitely categorized as the other of that 'Europe'; but, at the same time, it also perceived as a threat to the already fragile cohesion of the existing European self, epitomized by EU membership. This view of the EU, in turn, is reflected in the barometer polls about the EU; all the polls suggest that there is a clear desire for a more protective EU. Indeed, when asked about the future of Europe and what the EU should be doing, preserving economic and social standards are by far the top priorities. Fighting unemployment (71\%), promoting economic growth (32\%), and combating delocalisation (35\%) were the list of priorities in a national poll (Louis Harris 2006), and in the latest 2005 Eurobarometer poll, fighting unemployment (57\%) and fighting poverty (53\%) largely dominated (European commission 2005). The rejection of Turkey on pragmatic grounds seems therefore to suggest that the French consider that the EU should be adopting a fallback position to preserve the standards of existing members.

A similar conclusion can be drawn as far as defence and security are concerned given that security issues (terrorism, crime) are high on the list of concerns noted in the polls (European Commission 2005). Just as the French want a socially and economically more protective EU, they also ranked security issues among the main priorities of the EU for the future (European Commission 2005). This is reflected in the press. Robert Badinder (2005), for example, examines the consequences that Turkey's full membership could have for France and the rest of the EU by enhancing the nonEuropean characteristics of Turkey and reminding readers of one of the founding principles of the EU: 
rien ne justifie que l'Union européenne s'installe en Asie mineure, sur un territoire plus vaste que celui de la France et établisse des frontières communes avec l'Arménie, la Géorgie, l'Iran, l'Irak et la Syrie. Il n'y a pas de région du monde plus chargée de tensions et de menaces que celle-là. L'Union européenne a vocation à contribuer à sauvegarder la paix et à protéger les populations menacées, plutôt que de se trouver directement impliquée dans des conflits régionaux où la Turquie serait partie.

[Nothing can justify the EU expansion into Asia Minor, to a territory larger than France, and that shares borders with Armenia, Georgia, Iran, Iraq and Syria. No other region in the world is confronted by such tensions and threats. The raison d'être of the EU is to maintain peace and protect populations under threat rather than ending up directly involved in regional conflicts involving Turkey.]

The first set of arguments suggests that Turkey is rejected on utilitarian grounds. The stereotype at work here is that of a poor country threatening the well-being of existing EU members. The prototype is that of a Union whose main aim is to enhance and protect the economic and social standards of its existing members.

Ethical-political arguments are justifications that 'rely on a particular conception of the collective "us" and a particular idea of the values represented by a specific community" (Sjursen 2002, 494). These are 'kinship-based' arguments, that is the 'duties and responsibilities emerging as a result of belonging to a particular community' (494). In terms of enlargement, this means accepting new countries because they are part of 'our' community and share 'our' values. The analysis of opinion polls and articles from the previously mentioned newspapers reveals that Turkey is rejected because it is not perceived as belonging to Europe, whether geographically, historically and culturally. Many articles refers to these three facets and in the polls, 64\% mentioned that the cultural differences between the EU and Turkey were too great, 54\% felt that it did not historically belong to Europe, and 48\% that geographically it was not part of Europe (European Commission 2005). These arguments are most commonly cited as evidence of the incompatibility of Turkey's kinship with the EU, which would seem to suggest that French people see Europe as a cultural community. However, the prototype of the EU as a kinship-based community is difficult to define for two reasons. First, the majority of concepts used to define the EU by the French people are not kinship-based (peace, democracy, cooperation, freedom of movements, economic cooperation, and market economy). Second, when it comes to defining the shared or typical values of Europe only $23 \%$ of the French mention a common history, $22 \%$ a common cultural heritage, and $15 \%$ a common religious heritage drawn from Christian origins (European Commission 2006a), well behind any other kind of arguments. Furthermore, 
in a 2006 poll, $90 \%$ of respondents considered that Europe consisted of a variety of cultures but only $8 \%$ thought there was a European culture per sé (Louis Harris 2006). Not only is there no clear notion of European identity, but $42 \%$ of French people perceive French membership of the EU as a direct threat to their national culture and identity, whilst $26 \%$ consider, on the contrary, that membership protects national cultures and identities (TNS-Sofres 2005b). However, in the autumn 2005 Eurobarometer poll, 58\% of respondents said that they felt both French and European (European Commission 2005) and this figure rose to 60\% in 2006 (European Commission 2006a). Also, in 2005, 54\% of respondents revealed that they were rather proud of being European (European Commission 2005). Thus, alhough the attachment to the French identity is more prevalent and always supersedes a European identity, a large majority of French people do feel European. The prototype of a kinship-based Europe might be difficult to ascertain but the fact that Turkey is rejected because it is not perceived as being 'European' indicates the presence of a European 'us' versus a non-European 'them.'

Moral arguments are based neither on calculations of utility nor on references to the values of a particular community, but on 'universal standards of justice' (Sjursen 2002, 494). For example, enlargement can be justified by the need to consolidate democracy in the candidate states, as was the earlier case with Greece or Spain. Turkey is rejected on moral grounds because it has a poor record on human rights in general $(88 \%$ respondents in the latest 2005 Eurobarometer poll [European Commission 2005]) and women's rights in particular, minorities are not protected, and the Armenian genocide has not been recognised (Louis Harris 2004). National polls show that when asked specifically about the typical criticisms levelled at Turkey, $81 \%$ agreed that the refusal to recognise the Armenian genocide was a very serious stumbling block to Turkey joining the EU, 74\% said the same about the role of the Turkish army in the political system, $87 \%$ about the fact that minorities are not protected enough, and $90 \%$ about the non-respect of women (Louis Harris 2004). The results of the polls show that many French people share the question raised by Sylvie Goulard $(2004,35)$, a lecturer in political science:

Pouvons-nous vraiment, nous Français et Allemands, passer sous silence le refus turc de dénoncer le génocide arménien alors que nous sommes parvenus à l'apaisement en regardant l'Histoire en face? 
[Could we, the French and the German, really ignore Turkey's refusal to denounce the Armenian genocide when we have succeed in reaching a state of peace by facing up to our history?]

Not only are these questions perceived as legitimate, but, to a large extent, they are seen as a moral duty towards fellow members of the EU. French people extend the moral duty to question Turkey's claim that it shares the same values as the EU member countries to women and minorities' rights and therefore is qualified to join. Haddad Mezri $(2004,28)$ in 'Le marchand de tapis et la stripteaseuse' [The haggler and the stripper] points out that,

La Turquie d'en haut a beau se targuer d'avoir accordé à la femme le droit de divorce (1923), le droit de vote (1934), le droit à l'avortement (1987), la Turquie d'en bas continuera, jusqu'à ce jour, à pratiquer les 'crimes d'honneur,' les mariages forcés ou précoces ... et les violences les plus barbares.

[Privileged Turkey may boast about granting women the right to divorce (1923), the right to vote (1934), the right to abort (1987), but deprived Turkey will still, to this day, resort to "crimes of honour", arranged or underage marriages ... and the most barbaric violence.

Despite its claims, Turkey is not seen as being on a par with EU member countries. These discrepancies classify Turkey in the 'other' category. Michel Wieviorka (2005, 41), analysing the arguments of those against Turkey, extends this notion of otherness to the concepts of democracy and the secular republic. Turkey is defined as 'un pays non-démocratique qui ne progresserait pas comme il le devrait pour se conformer aux demandes de l'UE et qui ne devrait son allure républicaine qu'à un pouvoir militaire' [An undemocratic country that is not progressing as it should to meet EU standards and whose so-called republican regime only relies on the military]. This suggests that the EU is defined as an Etat de droit ${ }^{3}$ and, indeed, in various opinion polls conducted on the values shared by European citizens, the respect for human beings and their fundamental rights is rated by $44 \%$ of the French as one of the main values, if not the main value, most widely shared by EU citizens, closely followed by their attachment to democracy (43\%) (TNS-Sofres 2005b). The stereotype of Turkey and the prototype of the EU is unambiguous with this set of arguments. Turkey is seen as a non-democratic country that infringes human rights, whereas the EU is a democratically run community with human rights as its core political value.

\footnotetext{
${ }^{3}$ The concept according to which public authorities abide by the same laws as citizens whose rights are guaranteed by the state.
} 
We argue that despite the large number of pragmatic or moral arguments, the ethicalpolitical arguments are the most salient and at the root of the deep and generalised hostility towards Turkey joining the EU. The fact that in $200657 \%$ of French respondents asserted that even if Turkey were to meet all the conditions set for its full membership they would still be against the country joining the EU, and that between $30 \%$ and $38 \%$ declare that Turkey should never be part of the Union for historical and cultural reasons (European Commission 2006a), shows that Turkey belongs to an 'other' category beyond pragmatic or moral arguments. In an interview for Libération Jean-Louis Bourlanges $(2004,4)$ epitomises the prevalence of ethical-political arguments in the rejection of Turkey's membership when, leaving no doubt on the otherness of Turkey, he declares:

L'identité historique de l'Europe est indissociable, non des convictions religieuses des Européens aujourd'hui mais du modèle culturel et politique façonné par quinze siècles de christianisme .... La Turquie est étrangère à cette histoire, elle qui n'a pas connu la conversion romaine au christianisme, l'humanisme, la réforme, les lumières, le romantisme, etc ...

[The historical identity of Europe cannot be considered separately, not from the religious beliefs shared by European citizens nowadays but from the cultural and political model shaped by fifteen centuries of Christianity .... Turkey is alien to this history, it did not experience the Roman conversion to Christianity, Humanism, the Reformation, the enlightenment philosophers, Romanticism, etc ...]

A comparison with the 2004 enlargement provides further evidence of the prominence of ethical-political rejections of Turkey. Concerns were raised about the economic cost of the enlargement to the East (71\% felt that it would be very costly for France), its consequences on possible immigration, and its impact on unemployment ( $46 \%$ felt unemployment would increase), social provisions in France (46\% felt that the standards would decrease), and sectors such as agriculture (European Commission 2003a). Yet $74 \%$ felt that 'we' had a moral duty to reunify Europe and 64\% felt that enlargement was justified because the respective countries were historically and geographically part of Europe. All perceived negative consequences were apparently acceptable because these countries were seen as part of the European family. The polls corroborated Sjursen's contention that pragmatic or moral arguments could not possibly have been the sole explanation for the EU's attitude towards the 2004 candidate countries; rather, pragmatic worries or moral arguments were swept aside by kinship-based arguments (Sjursen 2002, 508). By extension, it can be argued that all the pragmatic and moral reasons used against Turkey could be swept aside as well but for the lack of kinship feelings towards Turkey. A comparison with another candidate state, Ukraine, illustrates 
this point: the current reasons used against the country joining the EU are very similar to the economic, social and political arguments against Turkey's entry, and yet 54\% would welcome Ukraine in the future if it meets all the conditions for accession, whereas $57 \%$ would reject Turkey even if it meets all those conditions.

It appears, therefore, that the key aspect in determining the EU rejection or the acceptance of another country is the feeling of kinship, which in this case could be referred to as the notion of Europeanness. If French people reject Turkey because it does not belong to Europe, i.e., it is not one of us, can a definition of the 'self' be drawn from the reasons given for this rejection? Can Turkey as the 'other' be the negative entity required for the common representation of the European self in France? What are the characteristics of this sort of Europeanness?

\section{The concept of Europeanness}

The question arises here whether or not geography might be the consensual criterion used to assess Europeanness, given it is one of the main reasons put forward against Turkey and is often suggested in the press. In his article 'La Turquie, alibi du oui et du non' [Turkey, the alibi of the "Yes" and the "No" supporters], the sociologist Michel Wieviorka $(2005,41)$ mentions the geographical arguments against Turkey's membership,

C'est un pays d'Asie, situé pour l'ensemble en dehors des frontières géographiques de l'Europe. D'ailleurs le fondateur de la Turquie moderne n'a-t-il pas choisi d'installer la capitale à Ankara, en Anatolie et non en Europe?

[This is an Asian country with most of its territory stretching beyond Europe's geographical boundaries. Besides, didn't the founding father of Modern Turkey choose Ankara as his capital city, the latter being located in Anatolia, and not in Europe?]

This argument suggests that even Turks themselves do not regard Turkey as belonging to Europe. The argument pointing out that $95 \%$ of Turkish territory is in Asia is a recurring one in the press, as illustrated by the 'argumentaire des partisans et des opposants à l'intégration' [List of arguments for and against Turkey's full membership] published in Le Monde in which Alain Lamassoure after examining the various ways to define a "European Zone" concludes that "le moins mauvais critère est la géographie. Le projet européen concerne toute l'Europe, et rien que l'Europe' [The least bad criterion is geography. The European project is about Europe as a whole and Europe only] (Clerc 2004). In other words, for Lamassoure, geographical arguments might not be perfect, 
but they are undeniable and valid. ${ }^{4}$ This view is also supported in the polls. In 2006, $47 \%$ of French people were of the opinion that definite borders should be agreed on before any further enlargement took place. Although 50\% thought that physical borders for the EU could not be defined, and that the EU should expand to any European country sharing its values (European commission 2006a), the reference to 'European countries' is clearly of a geographical nature. The EU is therefore perceived as a geographically bound entity that will eventually have clearly defined borders.

However, no consensual boundaries are neither specified (which are these 'European countries') nor less agreed upon, as reflected in the various debates published in the press, and evident in headlines such as 'Jusqu'où repousser les frontières de l'Europe?' [How far should Europe expand its borders?] (De Bresson 2004). An article in Libération, for example, 'La Turquie face à l'identité européenne' [Turkey versus European identity]' states that 'le débat sur l'adhésion de la Turquie à l'Union révèle la nécessité d'une redéfinition de l'Europe, ce qui passe forcément par un débat sur ses frontières' [The debate surrounding Turkey's membership highlights the need to rethink Europe's boundaries, which undeniably involves a debate on boundaries] (Laidi 2002,8). This suggests that French people seem to be unsure of what the borders of Europe should be, and in some cases, whether they should be physically defined at all, for to limit Europe to a geographical entity would restrict the concept of Europeanness itself. This argument is also developed in Le Monde, where Pascal Clerc (2002) states that geography is a 'pretext' used to reject Turkey. He notes:

La géographie a bon dos. Juge de paix, elle aurait donné à L'Europe ses limites intangibles, permettant ainsi de décider sans ambiguïté quels sont les Etats qui peuvent revendiquer leur intégration dans l'Union européenne et quels sont ceux qui doivent rester à la porte.

[For many, geography is an easy copout that supposedly gives Europe intangible limits, allowing a decision without any ambiguity about which countries can claim EU membership and which ones should remain on its door step.]

Deploring this fact, he points out that,

Les limites ne sont pas données par la nature, mais sont des productions culturelles. Fixées dans des contextes historiques précis et pour servir des projets particuliers, ces limites sont susceptibles d'être modifiées et doivent toujours être interrogées.

\footnotetext{
${ }^{4}$ Alain Lamassoure is a Member of the European Parliament for the south-west of France. He is a member of the Union for a Popular Movement, which is part of the European People's Party, and sits on the European Parliament's finance Committee. He also represented the European Parliament at the European Convention in 2002-2003.
} 
[Limits are not defined by nature but are cultural products. These limits have been drawn in specific historical contexts to serve particular purposes. They are likely to be moved and should always be questioned.]

If geography is not a consensual criterion, then, might Europe be seen as a community of values rather than simply a geographic entity?

Reference to values shared by European countries deployed to reject candidate states seems to suggest that a clear and homogenous set of values contributes to the shaping of a European identity. Indeed, in 2006, 66\% of French respondents agreed that the EU countries had common values, which make them different from the rest of the world (European Commission 2006a). Moreover, 71\% felt that these countries shared a common culture that deserved to be defended against other cultures (TNS-Sofres 2004). However, the analysis of French responses in polls carried out on European culture and values show that the terms 'culture' and 'values' cover a wide range of meanings. These meanings include economic considerations such as the Euro, which is often mentioned first, as if the shared currency itself grants the EU a federative status, prosperity, market economy, high standards of living, and social welfare (Louis Harris 2006; European Commission 2006a, 2006b). Although some of these meanings can be associated with the EU's concrete achievements, they are not particularly typically European in themselves. This applies, as well, to other values quoted by the French respondents, such as human rights, women's rights, democracy, peace and solidarity. If the most typical values shared by European citizens are of a cultural nature, a common history and a common religion are the only two cultural values mentioned by respondents, and by very few at that, $23 \%$ and $9 \%$ respectively (European Commission 2006a).

The reference to a common history blurs the notion of Europeanness further: how can a common history be defined if the geographic 'common' element is not clear? For example, Libération reported in 2002 that the then Foreign Minister, Hubert Védrine, was rightly concerned about the meaning of a European political project without welldefined borders. Védrine pointed out the deficiencies of a corpus of values that is not reflected in a specific territory (Duhamel 2002, 43). As religion is mentioned as a shared cultural value, should we assume that Europe is defined as Christian? Indeed, alongside geography, religion is often cited as undeniable evidence of the incompatibility of Turkey with the EU. For Ignacio Ramonet $(2004,1)$, writing in Le Monde Diplomatique, 
the debate surrounding Turkey's membership flags the current anxiety western societies have about their identity in relation to Islam. The debate epitomises the Islam-phobic feelings haunting virtually all political sectors. Since a significant proportion of Turkey's opponents see Islam as incompatible with Europe and its values, should we conclude then that Christianity is a typical European trait and therefore that what is not Christian is not European? With this argument, the perception of the other (of Europe) defined in religious terms would therefore give a clearer image of the European self. This is the argument put forward by Jean-Louis Harouel $(2005,12)$ in 'Le legs du Christianisme' [The Legacy of Christianity] published in Le Figaro, in which he states that 'Précisément, l'Europe est aujourd'hui ce qu'elle est grâce au fait qu'elle a refusé plus de mille ans durant de devenir musulmane' [Europe is what it is today thanks to its refusal to become Muslim for over a thousand years]. He adds:

\footnotetext{
C'est parce que l'Europe a été capable de chasser de son sol les dominations musulmanes ... que nous vivons dans une société laïque, libre, tolérante, économiquement développée, à haut niveau de vie moyen et socialement généreuse.

[It is only because Europe was able to drive out Muslim domination that it can today enjoy a secular society, freedom, tolerance, a developed economy, a high standard of living and social welfare.]
}

However, whilst considering that Islam provides a ground for the rejection of Turkey's entry into the EU (19\% in 2002 and 25\% in 2006 [Ipsos 2002; 2004]), the French cannot be said to perceive Christian heritage as being a federative trait of Europe that bonds European citizens, since so few of them mentioned it as a European value.

Turkey is rejected with kinship-based arguments, yet what European kinship might be is not clearly defined in the polls and the French press; the vast majority of values used to define the EU are pragmatic and the few cultural ones are imprecise or not clearly substantiated. The dichotomy between the EU defined by pragmatic arguments and Turkey being rejected on ethical-political grounds suggests that the rejection of the 'other' can generate a feeling of kinship around the rejection itself, rather than provide the rationale for this rejection. The strong opposition to Turkey's membership displayed both in opinion polls and the press seems undeniably more federative than the specific arguments that highlight why Turkey does not belong in and to Europe. Clearly, the rejection of Turkey on the basis of its differences, even if these differences are not consensual, is where the French-European consensus lies. Commonality in terms of Europeanness is yet to be defined in the French psyche, but the rejection of the 'other' 
brings a sense of commonality in itself. Commonality is derived from what is clearly rejected rather than what is vaguely shared. This process is emphasised in a press release from the CNRS in 2003 about one of its research programs on European identity:

L'identité européenne demeure en effet une notion ambigüe. De multiples visions du 'fait' européen s'enchevêtrent sans pour autant se superposer: la réalité historique de l'Europe ne coïncide pas avec les données physiques et géographiques, à tel point qu'il est pratiquement impossible de répondre à la question «qu'est-ce qu'un européen?». (...) L'accélération du processus de construction européenne conduit les citoyens comme les responsables politiques à s'interroger sur l'avenir des organisations fondées sur l'adéquation entre état, nation et territoire. Ces interrogations prennent place dans un contexte où se développent à la fois un sentiment de fragilité face aux processus de globalisation et des tentatives de reterritorialisation ou de réinvention d'identité dont le rapport au territoire semble précisément difficile à cerner.

[European identity remains an ambiguous notion. Multiple representations of Europeanness coexist without matching; the historical reality of Europe is not reflected by physical or geographical boundaries to the extent that it is virtually impossible to find an answer to "What is a European?" The increasing pace of the EU integration process is leading European citizens and politicians to question the future of organisations based on the relationship between States, nations and territories. These questions arise at a time when both the feeling of insecurity due to the globalisation process is increasing, and attempts to reclaim territory or re-invent an identity that is aligned with a territory are proving difficult to sustain.

Even if the status of a supranational state in the French standardised conception of Europe is granted, the EU remains an entity associated with a set of characteristics that do not confer on the EU any specific Europeanness. Drawing a parallel with Renan's attempt to define a nation through the exploration of history, geography, anthropology, religion or politics, we can only conclude that like the nation, Europeanness and Europe encompass too vast a set of characteristics to be limited by a strict definition other than the conscious and manifest will that EU member countries have of being brought together (Renan 1997). Our contention is that this desire is fuelled by a tangible sense of kinship; it is not derived from a clearly defined notion of Europeanness, but from a rejection based on a perception of non-European otherness, in this case, represented by Turkey itself.

\section{Conclusion}

Our analysis of the opinion polls and the press leads us to conclude that despite common reference to pragmatic and moral arguments, the prominence of ethicalpolitical arguments against Turkey's membership of the EU, as presented in the Sjursen model, shows that the feeling of kinship is the key element in determining the acceptance of the 'other.' The absence of the feeling of kinship will therefore lead to the 
rejection of 'the other,' as is well illustrated in the specific case of Turkey's application to join the EU. However, we also conclude that the French prototypical representation of Europe and Europeans cannot be drawn from their stereotypical representation of Turkey. This emphasizes the cognitive nature of the stereotypification process itself, and suggests that if the French have a clear image of what is not European, they do not necessarily have a clear consensual representation of what constitute Europeanness. At present, the only clear attempt at defining Europeanness is limited to the Copenhagen Criteria, which has no kinship dimensions. For Robert Badinder (2005), Turkey's potential membership of the EU emphasises the existing haziness surrounding Europe and what constitute Europeanness, except as the name for an ever-expanding trading market.

Could this mean that Europeanness is only currently associated with what is rejected on a kinship basis as opposed to what is accepted on that basis? Does the 'other' when regarded as a threat requiring group protection create a bond between members of a group? Turkey seems to epitomise the dangerous 'other' from whom the European 'self,' as perceived by French people, needs to be protected, but this 'self' is, at best, a concept riddled with many contradictions, and, at worst, an empty entity. The problematic lies, we suggest, in the lack of consistency by which citizens of EU member states in general, and France in particular, associate with the notion of Europe or Europeans in defining themselves. From this perspective, the issue of Turkey's membership is the trigger to more fundamental issues regarding the raison d'être of the $\mathrm{EU}$ and the direction it needs to take in the future. For that reason, we end with the words of the Green Party MEP, Gérard Onesta $(2005,1)$ :

\footnotetext{
Dans une Union en panne institutionnelle et budgétaire, et qui connaît des repliements nationalistes, la Turquie va peut-être d'avantage s'inscrire- et pour longtemps- dans le tempo des consultations électorales nationales que sur l'agenda communautaire. Pourtant la Turquie est un véritable sujet européen, puisqu'il pousse chacun à divulguer son projet sociétal et ses vues géopolitiques à long terme, ce qui est l'essence même de la construction de l'Union. Il est vrai que tous les élargissements qu'a connus l'histoire de l'Europe, c'est celui-ci, par sa nature et son ampleur, qui révèle le mieux les carences du processus européen. [In an EU at an institutional and financial standstill, couple with a movement of unprecedented nationalistic fallback positions, Turkey might be more prominent at the forefront of national debates brought about by various national elections than the Union's agenda. Yet, Turkey is a matter of true European importance, since it leads each of us to unveil one's longterm conception of society and geopolitics, the very essence of the Union. It is true to say that from all the previous enlargements in the history of the Union, it is this one (to Turkey), both by its nature and its scope, that highlights most the deficiencies of the European integration process.]
} 


\section{Reference list}

Amossy, R., \& Herschberg-Pierrot, A. 2004, Stéréotypes et Clichés, Nathan, Paris.

Badinter, R. 2005, 'Avec la Turquie, l'Europe Renonce,' Le Monde [Online]. Available: http://www.lemonde.fr/web/article/0,1-0,36-698845,0.html [Accessed: 20 Apr. 2006].

De Bresson, H. 2004, 'Jusqu'où repousser les frontières de l'Europe?,' Le Monde [Online]. Available: http://abonnes.lemonde.fr/web/article_theme/0,42-0@2-3214,36-364746@53-7646,0.html [Accessed: 27 June 2006].

Deutsch, K, Burrell, S.A., Kahn, R.A., Lee, M., Lichterman, M., Lindgren, R.E, Loewenheim, F. \& Wagenen, R.W. 1957, Political Community and the North Atlantic Area: International Organization in Light of Historical Experience, Princeton University Press, Princeton, NJ.

Dubois, D. \& Resche-Rigon, P. 1993, 'Prototypes ou Stéréotypes: Productivité et figement d'un concept,' in Lieux Communs, Topoi, Stéréotypes, Clichés, ed. C. Plantin, Kimé, Paris. Pp372-389.

Duhamel, A. 2002, 'La realpolitik d'Hubert Védrine,' Libération, 14 Dec., 43.

Cautrès, B. 2003, 'Le CNRS à l'heure de l'Europe,' Théma CNRS, no. 1.

Clerc, P. 2002, 'Turquie: La Géographie Prétexte,' Le Monde [Online]. Available: http://abonnes.lemonde.fr/web/article/0,1-0@2-3232,36-298538,0.html [Accessed : 25 Apr. 2006].

Eichenberg, R.C. \& Dalton, R.J. 1993, 'Europeans and the European Community: The Dynamics of Public Support for European Integration,' International Organization, vol.47, no. 4, 507-34.

European Commission 2002, L'Opinion Publique dans l'Union Européeenne- Eurobaromètre 58 [Online].Available: http://ec.europa.eu/public_opinion/standard_fr.htm [Accessed: 10 Apr. 2006]. 2003a, L'élargissement de l'Union Européenne - Flash Eurobāromètre 140 [Online].Available: http://ec.europa.eu/public_opinion/archives/flash_arch_fr.htm [Accessed: 10 Apr. 2006]. 2003b, L'Opinion Publique dans l'Union Européeenne- Eurobaromètre 60 [Online].Available: http://ec.europa.eu/public_opinion/standard_fr.htm [Accessed: 10 Apr. 2006]. 2004, L'Opinion Publique dans l'Union Eüropéeenne- Eurobaromètre 62 [Online].Available: http://ec.europa.eu/public_opinion/standard_fr.htm [Accessed: 10 Apr. 2006]. 2005, L'Opinion Publique dans l'Union Européeenne- Eurobaromètre 64 [Online].Available: http://ec.europa.eu/public_opinion/standard_fr.htm [Accessed: 10 Apr. 2006]. 2006a, Quelle Europe? La Construction Européenne Vue par les Français - Flash Eurobaromètre 178 [Online]. Available: http://ec.europa.eu/public_opinion/archives/flash_arch_fr.htm [Accessed: 15 Apr. 2006]. 2006b, Le futur de l'Europe-Flash Eurobaromètre $1 \overline{4} 0$ [Online]. Available: http://ec.europa.eu/public_opinion/archives/flash_arch_fr.htm [Accessed: 10 Apr. 2006].

Fishman, J. 1956, 'An Examination of the Process of Social Stereotyping,' The Journal of Social Psychology, vol.43, 27-64.

Goulard, S. 2004, 'Le processus prématuré d'adhésion de la Turquie met en péril la cohérence européenne,' Libération, 8 Oct., 35.

Harouel, J.L. 2005, 'Le Leg du Christianisme,' Le Figaro, 5 Oct., 12.

Ifop 2005, Les Français et l'Adhésion de la Turquie à l'Union Européenne à la Veille du Début des Négociations [Online]. Available: http://www.ifop.com/europe/sondages/opinionf/turquie.asp [Accessed: 22 Apr. 2006].

Ipsos 2002, Les Français et l'Adhésion de la Turquie à l'Union Européenne [Online]. Available: http://www.ipsos.fr/CanalIpsos/poll/7703.asp [Accessed: 20 Apr. 2006]. 2004, Les Français et l'Adhésion de la Turquie à l'Union Européenne [Online]. Available: http://www.ipsos.fr/CanalIpsos/poll/7980.asp [Accessed: 20 Apr. 2006].

Kleiber, G. 1990, La Sémantique du Prototype, PUF, Paris.

Habermas, J. 1993, Justification and Application: Remarks on Discourse Ethics, trans. C.P. Cronin, MIT Press, Cambridge MA.

Laidi, Z. 2004, 'La Turquie face à l'identité européenne,' Libération, 20 Dec., 8.

Le Monde 2004, La Turquie appartient-elle à l'Europe. Le Monde Thématique [Online]. Available: http://abonnes.lemonde.fr/web/thematique/0,42-0@2-3214,53-7646,0.html. [ Accessed: 30 June 2006.]

Louis-Harris 2004, Les Français, l'Entrée de la Turquie dans l'Union Européenne et le Génocide Arménien [Online]. Available:

http://www.lh2.fr/_upload/ressources/sondages/europe/lhfaypfmadhe9siondelaturquie2324avril.pdf [Accessed: 25 Apr. 2006]. 2005, Sondage Post-Electoral Référendum sur le Traité Constitutionnel Européen [Online]. Available: http://www.lh2.fr/_upload/ressources/sondages/europe/LHFLibeiTeleReferPostElec30 mai05.pdf [Accessed: 25 Apr. 2006]. 
2006, Le Baromètre Européen [Online]. Available: http://www.lh2.fr/_upload/ressources/ sondages/europe/lh2artebaro_europeenavril06.pdf [Accessed: 25 Apr. 2006].

Mandraud, I 2005, Le processus d'adhésion de la Turquie à L'UE avive les tensions au PS et à droite. Le Monde[online] Available : http://abonnes.lemonde.fr/web/article theme/0,42-0@2-3224,36694803@53-694820,0.html. [ Accessed: 27 June 2006.]

Mezri, H. 2004, 'Le marchand de tapis et la stripteaseuse,' Libération, 31 Dec., 28.

Nachbar, J., and Lause, K. 1992, Popular Culture: An Introductory Text, Bowling Green University Press, Bowling Green

Onesta, G. 2005, 'Querelles Byzantines?' Carré D’Europe, 31 Oct., 1. .

Ramonet, I. 2004, 'Turquie,' Le Monde Diplomatique, Nov., 1.

Renan, E. 1997, Qu'est-ce qu'une Nation?, Mille et une nuits, Paris.

Sjursen, H.2002,'Why Expand? The Question of Legitimacy and Justification in the EU's Enlargement Policy,' Journal of Common Market Studies, vol.40,n○3, 491-513.

TNS-Sofres 2004, Les Français et l'Europe [Online]. Available: http://www.tnssofres.com/etudes/pol/240504_europe_n.htm [Accessed: 15 Apr. 2006]. 2005a, Les Européeens et l'Adhésion de l'Ukraine à l'Union Européenne [Online]. Available: http://www.tns-sofres.com/etudes/pol/250305_ukraine_n.htm [Accessed: 15 Apr. 2006]. 2005b, L'Europe Vue par les Européens [Online]. Available: http://www.tnssofres.com/etudes/pol/051005_europe_n.htm [Accessed: 15 Apr. 2006]. 2006, Quelle Europe ? La Construction Européenne Vue par les Français [Online]. Available: http://www.tns-sofres.com/etudes/pol/170306_europe.htm [Accessed: 15 Apr. 2006].

Wieviorka, M. 2005, 'La Turquie, alibi du oui et du non,' Libération, 14 Jun., 41. 